\title{
Genetic parameters for type classification of Nelore cattle on central performance tests at pasture in Brazil
}

\author{
Paulo Ricardo Martins Lima • Samuel Rezende Paiva • \\ Jaime Araujo Cobuci • José Braccini Neto • \\ Carlos Henrique Cavallari Machado • \\ Concepta McManus
}

Accepted: 22 March 2013 / Published online: 9 April 2013

(C) Springer Science+Business Media Dordrecht 2013

\begin{abstract}
The objective of this study was to characterize Nelore cattle on central performance tests in pasture, ranked by the visual classification method EPMURAS (structure, precocity, muscle, navel, breed, posture, and sexual characteristics), and to estimate genetic and phenotypic correlations between these parameters, including visual as well as production traits (initial and final weight on test, weight gain, and weight corrected for 550 days). The information used in the study was obtained on 21,032 Nelore bulls which were participants in the central performance test at pasture of the Brazilian
\end{abstract}

This study was supported by INCT Pecuária CNPq/FAPEMIG and CAPES.

P. R. M. Lima

Faculdade de Agronomia e Medicina Veterinária,

Universidade de Brasília, Brasilia, Federal District 70910-900,

Brazil

e-mail: paulor@zootecnista.com.br

S. R. Paiva

EMBRAPA Recursos Genéticos e Biotecnologia,

PqEB, Final W5 Norte, Brasilia, Federal District, Brazil

e-mail: samuel.paiva@embrapa.br

J. A. Cobuci $\cdot$ J. B. Neto $\cdot$ C. McManus $(\bowtie)$

Departamento de Zootecnia, Universidade Federal do Rio Grande

do Sul, Porto Alegre, Rio Grande do Sul, Brazil

e-mail: concepta.mcmanus@ufrgs.br

\section{J. A. Cobuci}

e-mail: jaime.cobuci@ufrgs.br

J. B. Neto

e-mail: jose.braccini@ufrgs.br

\section{H. C. Machado}

Associação Brasileira dos Criadores de Zebu, ABCZ,

Praça Vicentino R. da Cunha, 110, Parque Fernando Costa,

38022-330, Uberaba, Minas Gerais, Brazil
Association for Zebu Breeders (ABCZ). Heritabilities obtained were from 0.19 to 0.50 . Phenotypic correlations were positive from 0.70 to 0.97 between the weight traits, from 0.65 to 0.74 between visual characteristics, and from 0.29 to 0.47 between visual characteristics and weight traits. The genetic correlations were positive ranging from 0.80 to 0.98 between the characteristics of structure, precocity and musculature, from 0.13 to 0.64 between the growth characteristics, and from 0.41 to 0.97 between visual scores and weight gains. Heritability and genetic correlations indicate that the use of visual scores, along with the selection for growth characteristics, can bring positive results in selection of beef cattle for rearing on pasture.

Keywords Clusters $\cdot$ Heritabilities $\cdot$ Visual assessment

\section{Introduction}

MAPA (2010) projects a growth rate of $2.15 \%$ per year for beef production in Brazil, reaching 10 million tons of meat/year by 2020 . These projections are shared by abattoirs, who, for producing more demanding foreign markets, require carcasses with high weights, good degree of finishing, and maximum age at slaughter of 36 months (Metz et al. 2009). The national herd must therefore become more commercially competitive, and the farmer is increasingly seeking new methods to enhance economic aspects of production (Barcellos et al. 2011). The Nelore is the main breed in tropical regions in Brazil so it has a strategic importance for Brazil's gross national product as the world's largest beef exporter.

While subjective linear type traits have been used in dairy cattle to improve functional characteristics (Vallimont et al. 2010), these are less widely used in beef cattle. Most selection for beef cattle in Brazil is based on weight for age and scrotal 
circumference, but some studies have used visual assessments, with scores for morphological characteristics in beef cattle, to identify individuals who have good functional traits
(Faria et al. 2008). These include scores for production traits, conformation $(\mathrm{C})$, precocity $(\mathrm{P})$, and musculature $(\mathrm{M})$ within test groups. Early systems encountered problems with the use
Fig. 1 Scores for breed, posture, sexual characteristics (a), navel (b) as well as stucture, precocity and musculature (c) of Nelore cattle on central performance test at pasture in Brazil a
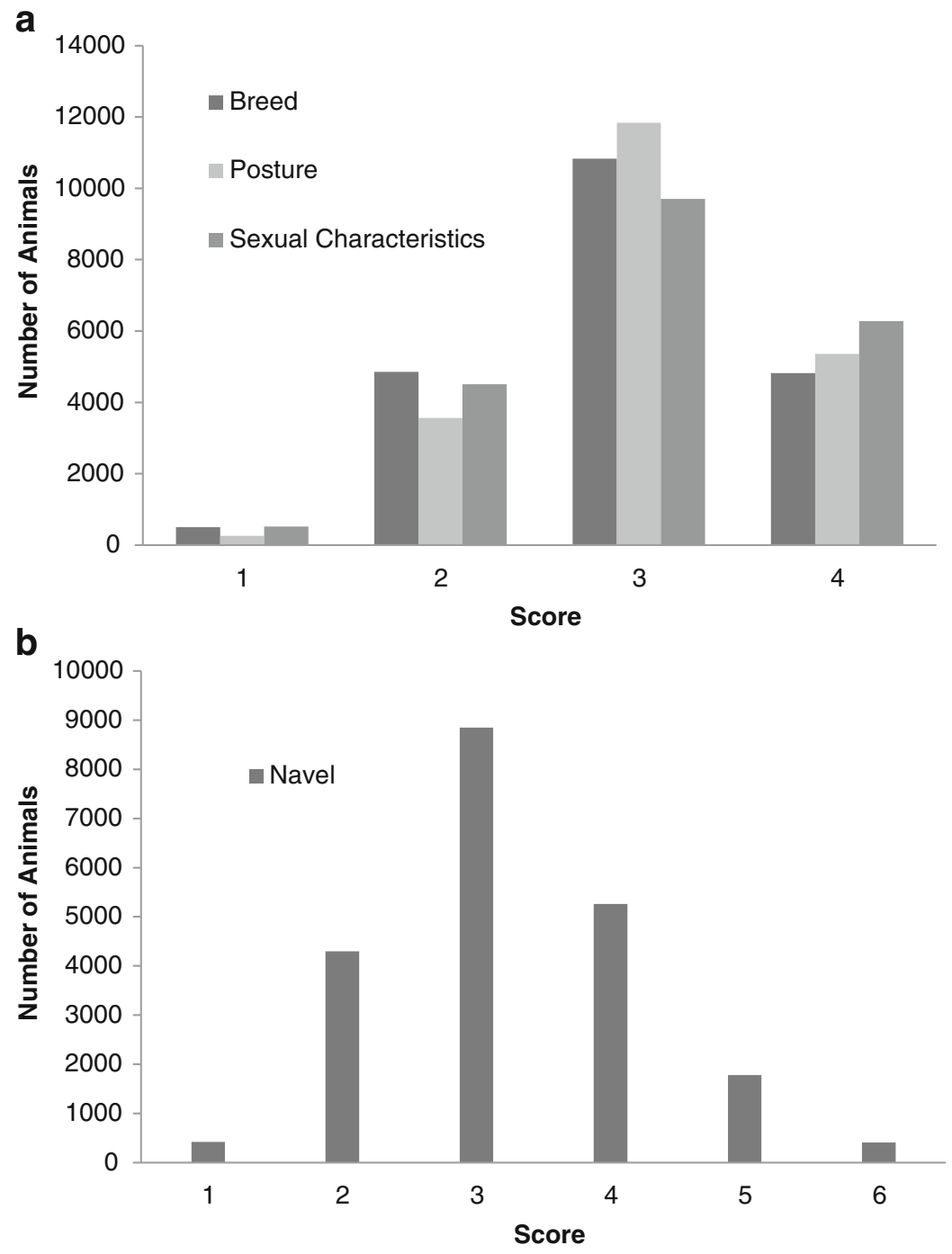

C

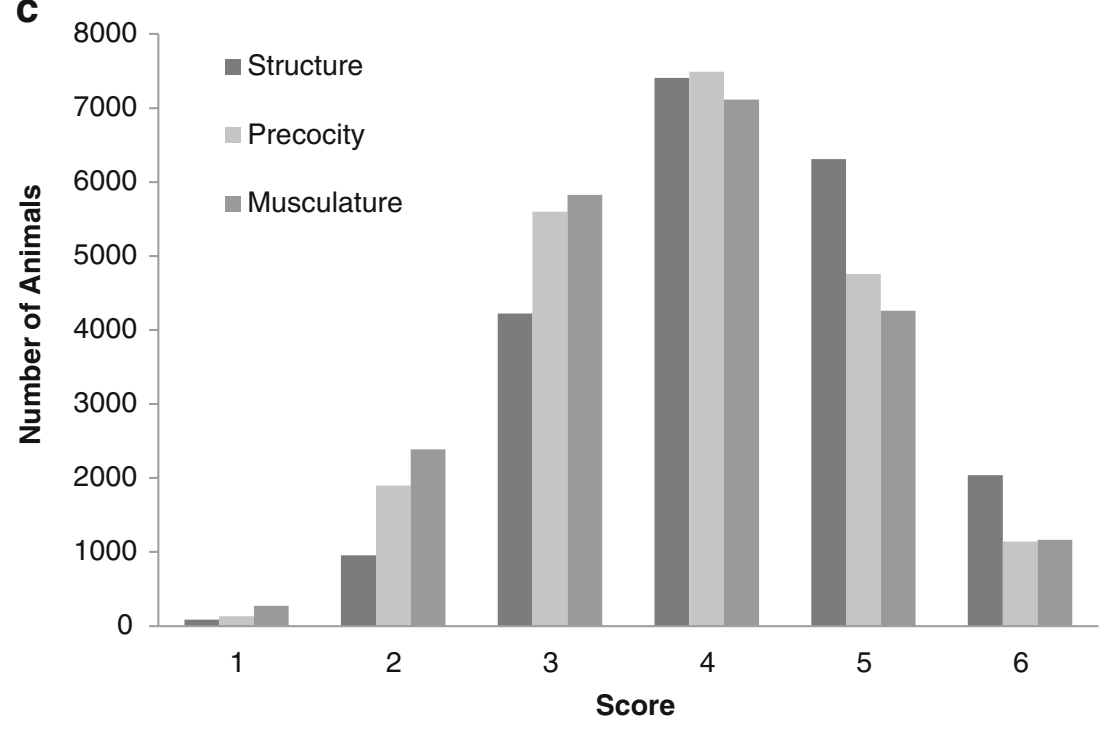


of morphological traits as selection tools due to the absence of linearity in some traits (Gutiérrez and Goyache 2002). These linear type evaluations aim to reflect muscular, skeletal, and functional characteristics of animals, and it has been seen that some type traits are useful indicators of the overall profitability in beef cows (McHugh et al. 2012).

The EPMURAS linear classification system was developed by Koury Filho et al. (2003) and is becoming more widely used in breeding programs in Brazil, as cattle production is becoming more concerned about meat and carcass traits, reproduction, as well as animal welfare issues (Ferraz and Felício 2010). In this system, animals receive a score for structure (E), precocity (P), muscle (M), navel (sheath, umbilicus) (U), breed (race) standard (R), posture (A), and sexual characteristics $(\mathrm{S})$. Individuals are not compared with their test group but to the standards defined by the association. Little information is available on the (co)variance estimates for these subjective traits or their correlations with growth and reproductive traits. The objective of this work was to investigate the relationships between type and production traits in Nelore cattle on central performance tests at pasture in Brazil as well as estimate genetic and phenotypic parameters for these.

\section{Material and methods}

Information on weights and visual scores was obtained between 2004 and 2010, on 21,032 Nelore bulls, from farms distributed throughout Brazil, which were participants of central performance tests at pasture (PGP) of the Zebu Breeding Program-PMGZ managed by the Brazilian Association of Zebu Breeders-ABCZ. This PGP is used to assess purebred males, with a maximum age range of 90 (ninety) days for animals on the same test.
Connectability between test groups (TGs) was performed using AMC (Roso and Schenkel 2006) based on the total number of genetic ties (minimum of ten). This showed that $99.39 \%$ (20,922 animals) belonged to a single population, with the three TGs shown to be disconnected $(0.61 \%$ or 109 animals) which were removed from the analysis.

All animals were purebred Nelore with both parents identified. Each test had the same management and feeding system used to evaluate weight gain, final weight, and type. Each test had at least 20 animals from three sires to form a test group. These were sons of 1,805 sires with at least four sons on at least two of the 488 tests, with on average 117 sons per sire, varying between 30 and 352 .

PGPs lasted for 294 days (70 adaptation and 224 effective test days). Tests included animals from a single herd or different herds. The animals were weighed in the morning after a 12-h fasting at the start of the adaptation period, start and end of the test, as well as every 56 days in between. After the final weighing, each animal underwent a visual inspection using the EPMURAS evaluation method. Individuals are not compared with their test group but to standards defined by the association. The animal received a score for EPMURAS (Fig. 1). E, P, M, and U received a score from 1 to 6 , while $\mathrm{R}, \mathrm{A}$, and $\mathrm{S}$ from 1 to 4 . The score for $\mathrm{U}$ varied from 1 (small and tight to the animal's body) to 6 (large and pendulous).

Birth weight (BW), initial test weight (IW) (or yearling weight), final weight $(\mathrm{FW})$, and growth rate $(\mathrm{DWG})=(\mathrm{FW}-$ IW)/number of days on test were also taken. Age at the start (AGE_S) and end (AGE_E) of test are used to calculate weight corrected for 550 days $($ WT550) $=$ $((F W-I W) \times 550+B W) /\left(A G E \_E-A G E \_S\right)$. A final test index (IPGP) was calculated as follows:
Table 1 Central tendency measures and percentages per class for EPMURAS scores in Nelore cattle on central performance test in Brazil

$E$ body structure, $P$ early maturing, $M$ muscle, $U$ navel, $R$ breed pattern, $A$ posture, $S$ sexual characteristics

${ }^{\mathrm{a}} 1$ and 2 are inferior, 3 and 4 are intermediate, and 5 and 6 are superior

${ }^{b} 3$ to 4 are the best scores

${ }^{\mathrm{c}} 1$ = weak, $2=$ regular, $3=$ good, and $4=$ very good

\begin{tabular}{|c|c|c|c|c|c|c|c|}
\hline & $E^{a}$ & $\mathrm{P}^{\mathrm{a}}$ & $\mathrm{M}^{\mathrm{a}}$ & $\mathrm{U}^{\mathrm{b}}$ & $\mathrm{R}^{\mathrm{c}}$ & $\mathrm{A}^{\mathrm{c}}$ & $\mathrm{S}^{\mathrm{c}}$ \\
\hline \multicolumn{8}{|c|}{ Tendency measure } \\
\hline Skewness & -0.197 & -0.051 & -0.027 & 0.382 & -0.267 & -0.308 & -0.372 \\
\hline Kurtosis & -0.345 & -0.428 & -0.437 & 0.059 & -0.351 & -0.124 & -0.510 \\
\hline Mean & 4.19 & 3.87 & 3.77 & 3.23 & 2.95 & 3.06 & 3.03 \\
\hline Mode & 4.00 & 4.00 & 4.00 & 3.00 & 3.00 & 3.00 & 3.00 \\
\hline Median & 4.00 & 4.00 & 4.00 & 3.00 & 3.00 & 3.00 & 3.00 \\
\hline $\mathrm{K}-\mathrm{S}$ & $P<0.01$ & $P<0.01$ & $P<0.01$ & $P<0.01$ & $P<0.01$ & $P<0.01$ & $P<0.01$ \\
\hline \multicolumn{8}{|c|}{ Percentage of animals in each class } \\
\hline 1 & 0.42 & 0.63 & 1.29 & 2.02 & 2.38 & 1.24 & 2.48 \\
\hline 2 & 4.54 & 9.04 & 11.35 & 20.46 & 23.12 & 16.95 & 21.45 \\
\hline 3 & 20.08 & 26.63 & 27.72 & 42.07 & 51.54 & 56.31 & 46.20 \\
\hline 4 & 35.24 & 35.65 & 33.84 & 25.02 & 22.86 & 25.51 & 29.88 \\
\hline 5 & 30.02 & 22.62 & 20.27 & 8.47 & - & - & - \\
\hline 6 & 9.69 & 5.42 & 5.53 & 1.96 & - & - & - \\
\hline
\end{tabular}


Table 2 Variables, means, standard deviations, maximum and minimum score and coefficient of variation $(\mathrm{CV})$ of traits used in the evaluations of Nelore cattle at pasture

\begin{tabular}{lrrrrr}
\hline Trait & Mean & Maximum & Minimum & CV & $\begin{array}{r}\text { Standard } \\
\text { deviation }\end{array}$ \\
\hline $\begin{array}{l}\text { Daily gain } \\
\quad(\mathrm{kg} / \text { days) }\end{array}$ & 0.56 & 1.18 & 0.00 & 29.56 & 0.16 \\
Birth weight (kg) & 32.10 & 58.00 & 20.00 & 10.02 & 3.22 \\
Start weight (kg) & 232.93 & 440.00 & 105.00 & 15.72 & 36.62 \\
Final weight (kg) & 357.42 & 593.00 & 164.00 & 15.75 & 56.28 \\
Age at start (days) & 330.20 & 373.00 & 252.00 & 7.19 & 23.75 \\
Final age (days) & 554.20 & 597.00 & 476.00 & 4.29 & 23.75 \\
Weight 550 (kg) & 354.86 & 600.25 & 171.40 & 15.10 & 53.58 \\
\hline
\end{tabular}

$$
\begin{aligned}
I P G P= & (0.4 \times D W G)+(0.4 \times W T 550) \\
& +(0.2 \times(E+P+M+U+R+A+S)) .
\end{aligned}
$$

To use $\mathrm{U}$ in IPGP, a score of 6 was converted to 1 and 5 to 2 to reflect the fact that values 3 and 4 are more desirable in accordance with $\mathrm{ABCZ}$ rules.

As the models used assumed a normal distribution of data, Box-Cox transformations were used (Neter et al. 1996). The same fixed effects were significant when using the transformed variables showing that linear modeling was robust enough to handle the initial measures.

Data were analyzed to determine effects of test group on scores and measures (MIXED), correlations (CORR), factor analysis (FACTOR), formation of groups (FASTCLUS, CLUSTER and TREE), discriminant analyses (STEPSISC, DISCRIM), using SAS ${ }^{\circledR}$. Dependent variables included growth rate, birth weight, initial test weight, final weight, as well as $\mathrm{E}, \mathrm{P}, \mathrm{M}, \mathrm{U}, \mathrm{R}, \mathrm{A}$, and S. Principal component analysis was used to examine the relationships between these traits. Cluster formation was based on a non-hierarchical method (no predefined groups) using weights and scores. Discriminant analyses were then carried out to investigate which traits were important in separating the animals into clusters and the possibility of correctly classifying animals into their clusters using this method.

(Co)variance components and heritability were estimated using maximum restricted likelihood free of derivatives under an animal model using multiple-trait derivative-free restricted maximum likelihood (MTDFREML) by Boldman et al. (1995), adjusting the equation

$y=X b+Z_{1} a+e$,

where $\mathbf{y}$ is a vector $(N \times 1)$ of observations on the animal (growth rate, weights at birth, start and end of the test, and corrected for 550 days of age, as well as $\mathrm{E}, \mathrm{P}, \mathrm{M}, \mathrm{U}, \mathrm{R}, \mathrm{A}$, and $\mathrm{S}$ ); $\mathbf{b}$ is the vector of fixed effects associated with the incidence matrix $\mathbf{X}$; $\mathbf{a}$ is the vector of direct genetic effects associated with the incidence matrix $\mathbf{Z}_{1}$; and $\mathbf{e}$ is the vector of random residuals. The expectations $(E)$ of the variables are assumed as $\mathrm{E}(\mathbf{y})=\mathbf{X b}$ and $E(\mathbf{a})=E(\mathbf{e})=0$. Residual effects, including random environmental and non-additive genetic effects, are independently distributed with variance $\sigma_{e}^{2}$. Therefore, $\operatorname{var}(\mathbf{e})=\mathbf{I} \sigma_{\mathbf{e}}^{2}, \operatorname{var}(\mathbf{a})=\mathbf{A} \sigma_{\mathbf{a}}^{2}$ and $\operatorname{cov}(\mathbf{a}, \mathbf{e})=$ $\operatorname{cov}(\mathbf{e}, \mathbf{a})=0$, where $\mathbf{A}$ is the numerator relationship matrix. The convergence criterion used was $10^{-9}$.

For phenotypic and genetic correlation calculation, a bi-character model was used:

$$
\left[\begin{array}{l}
y_{1} \\
\mathbf{y}_{2}
\end{array}\right]=\left[\begin{array}{cc}
\mathbf{X}_{1} & \Phi \\
\Phi & \mathbf{X}_{2}
\end{array}\right]\left[\begin{array}{l}
\mathbf{b}_{1} \\
\mathbf{b}_{2}
\end{array}\right]+\left[\begin{array}{cc}
\mathbf{Z}_{1} & \Phi \\
\Phi & \mathbf{Z}_{2}
\end{array}\right]\left[\begin{array}{l}
\mathbf{a}_{1} \\
\mathbf{a}_{2}
\end{array}\right]+\left[\begin{array}{l}
\mathbf{e}_{1} \\
\mathbf{e}_{2}
\end{array}\right],
$$
where $\mathbf{y}_{\mathrm{i}}$ is a vector of the observations for the $i$ th character; $\mathbf{b}_{\mathrm{i}}$, the vector of fixed effects; $\mathbf{a}_{i}$, the vector of animal effects; $\mathbf{e}_{i}$, vector of residual effects; $\mathbf{X}_{\mathrm{i}}$ and $\mathbf{Z}_{\mathrm{i}}$, index matrices; and $\boldsymbol{\Phi}$, a null matrix.

Dependent variables included growth rate, weights (initial, final, and corrected for 550 days of age), structure, precocity,
Table 3 Phenotypic (above the diagonal) and genetic (below the diagonal) correlations between the performance characteristics of Nelore cattle at pasture using fixed test groups
$E$ body structure, $P$ precocity, $M$ muscling, $U$ navel, $R$ breed pattern, $A$ posture, $S$ sexual characteristics, $D W G$ growth rate, $W T 550$ weight adjusted for 550 days of age, $I W$ initial test weight, $F W$ final weight, $I P G P$ final test index

\begin{tabular}{lllllllllllll}
\hline & DWG & WT550 & IW & FW & E & P & M & U & R & A & S & IPGP \\
\hline DWG & - & 0.77 & 0.33 & 0.76 & 0.29 & 0.29 & 0.31 & 0.08 & 0.18 & 0.12 & 0.26 & 0.77 \\
WT550 & 0.25 & - & 0.70 & 0.97 & 0.42 & 0.36 & 0.39 & 0.14 & 0.20 & 0.12 & 0.34 & 0.99 \\
IW & 0.27 & 0.67 & - & 0.77 & 0.44 & 0.34 & 0.36 & 0.17 & 0.17 & 0.09 & 0.31 & 0.71 \\
FW & 0.13 & 0.64 & 0.96 & - & 0.49 & 0.43 & 0.45 & 0.16 & 0.23 & 0.14 & 0.37 & 0.97 \\
E & 0.61 & 0.41 & 0.40 & 0.39 & - & 0.65 & 0.65 & 0.19 & 0.29 & 0.13 & 0.36 & 0.47 \\
P & 0.90 & 0.83 & 0.59 & 0.81 & 0.93 & - & 0.74 & 0.20 & 0.30 & 0.16 & 0.40 & 0.41 \\
M & 0.66 & 0.91 & 0.73 & 0.90 & 0.80 & 0.98 & - & 0.19 & 0.33 & 0.18 & 0.41 & 0.44 \\
U & 0.44 & 0.32 & 0.28 & 0.34 & 0.72 & 0.89 & 0.65 & - & 0.13 & 0.05 & 0.16 & 0.15 \\
R & 0.70 & 0.17 & 0.18 & 0.18 & 0.87 & 0.53 & 0.88 & 0.90 & - & 0.31 & 0.46 & 0.23 \\
A & 0.18 & 0.54 & 0.59 & 0.55 & 0.54 & 0.27 & 0.27 & 0.73 & 0.87 & - & 0.34 & 0.14 \\
S & 0.97 & 0.87 & 0.79 & 0.89 & 0.90 & 0.97 & 0.94 & 0.72 & 0.91 & 0.93 & - & 0.37 \\
IPGP & 0.54 & 0.65 & 0.91 & 0.64 & 0.73 & 0.89 & 0.66 & 0.91 & 0.24 & 0.83 & 0.64 & - \\
\hline
\end{tabular}


Table 4 Univariate heritabilities with fixed and random test groups for performance characteristics and visual scores of Nelore cattle on central performance test at pasture

\begin{tabular}{|c|c|c|c|c|}
\hline \multirow[t]{2}{*}{ Trait } & \multicolumn{4}{|l|}{ Heritability } \\
\hline & $\mathrm{UF}^{*}(\mathrm{SD})^{\mathrm{a}}$ & AIC & $\mathrm{UR}^{* *}(\mathrm{SD})^{\mathrm{a}}$ & AIC \\
\hline DWG & $0.26( \pm 0.022)$ & $-80,588$ & $0.06( \pm 0.006)$ & -81943 \\
\hline FW & $0.50( \pm 0.027)$ & 161,015 & $0.15( \pm 0.011)$ & 165,269 \\
\hline WT550 & $0.46( \pm 0.039)$ & 79,061 & $0.14( \pm 0.015)$ & 83,297 \\
\hline $\mathrm{E}$ & $0.26( \pm 0.023)$ & 15,647 & $0.19( \pm 0.017)$ & 15,549 \\
\hline $\mathrm{P}$ & $0.34( \pm 0.024)$ & 16,918 & $0.25( \pm 0.019)$ & 16,841 \\
\hline M & $0.28( \pm 0.022)$ & 19,000 & $0.20( \pm 0.017)$ & 18,965 \\
\hline $\mathrm{U}$ & $0.43( \pm 0.026)$ & 16,464 & $0.36( \pm 0.023)$ & 16,224 \\
\hline $\mathrm{R}$ & $0.18( \pm 0.019)$ & 5,377 & $0.15( \pm 0.016)$ & 4,820 \\
\hline A & $0.06( \pm 0.012)$ & -211 & $0.05( \pm 0.009)$ & -629 \\
\hline $\mathrm{S}$ & $0.18( \pm 0.019)$ & 5,556 & $0.13( \pm 0.015)$ & 5,192 \\
\hline IPGP & $0.21( \pm 0.023)$ & 56,111 & $0.11( \pm 0.033)$ & 56,113 \\
\hline
\end{tabular}

*UF univariate analysis with fixed test group

**UR univariate analysis with random test group

${ }^{\text {a }}$ AIC or Akaike Information Criterion response where the lowest result of a trait is most appropriate

$D W G$ growth rate, $F W$ final weight on test, $W T 550$ calculated weight at 550 days, $E$ body structure, $P$ early maturing, $M$ muscle, $U$ navel, $R$ breed standard, $A$ posture, $S$ sexual characteristics, IPGP final test index, $S D$ standard deviation

muscle, navel, breed, sexual characteristics, and posture. TG groups were tested as fixed or random in both univariate and bivariate analyses, and three different information criteria (Akaike (AIC), $-2 \log \mathrm{L}+2 k$ where $k$ is the number of parameters; Baysean (BIC), $-2 \log L+$ $k \log (n)$ where $n$ is the number of observations; and conditional AIC, $-2 \log \mathrm{L}+k(\log (n)+1))$ were used to select the best model. As results were consistent for all three, only AIC is presented.

\section{Results and discussion}

Conceptually, higher scores are better except for navel (sheath) score, where 3 to 4 are the best scores. The navel is important for Zebu-type cattle. Bignardi et al. (2011) stated that bulls with long foreskin or a tendency to expose the foreskin membrane are subject to inflammation, injury, and trauma. For the navel (Table 1), the average (3.23) was slightly higher than that found by Koury Filho et al. (2003) who found 3.09 for Nelore. This implies that the positioning of the navel, prepuce, and sheath, on average, are suitable for animals at pasture (Josahkian et al. 2003).

$\mathrm{E}$ and $\mathrm{P}$ had mean scores of 4.19 and 3.87, respectively, in line with those described by Faria et al. (2010) and Koury Filho et al. (2009) for the same breed. Animals in this study present a relatively large area for meat and fat deposition of meat at an early age. The average for $\mathrm{M}$ was 3.77 , higher than that found by Faria et al. (2010) and Koury Filho et al. (2010) who reported scores of 3.60 and 3.00, respectively. Koury Filho et al. (2009) found a score of 3.80.

The initial weight on test was $232.93 \mathrm{~kg}$ with a mean age of 330.20 days (Table 2) and weight corrected for 365 days was $257.48 \mathrm{~kg}$, higher than found by Malhado et al. (2010) who obtained $229.16 \mathrm{~kg}$ at 365 days with Nelore animals reared at pasture in Northern Brazil and close to that seen by Yokoo et al. (2010), which was adjusted for 365 days to $250.39 \mathrm{~kg}$. Average final weight adjusted for 550 days was $354.71 \mathrm{~kg}$, close to that described by Yokoo et al. (2010) with $347.14 \mathrm{~kg}$ and by Koury Filho et al. (2009) who reported $330.91 \mathrm{~kg}$ with a mean age of 523.10 days. The weight gain of $124.49 \mathrm{~kg}$ in 224 trial days was higher than that found by Conceição et al. (2005) who found a gain between 365 and 550 days of age of $83 \mathrm{~kg}$ in Polled Nelore raised under pasture conditions. Differences in genetic makeup and management of the animals (nutritional, handling, age at testing, length of evaluation
Fig. 2 Graphical representation of the first two principal components, growth characteristics, and visual assessments in Nelore cattle at pasture

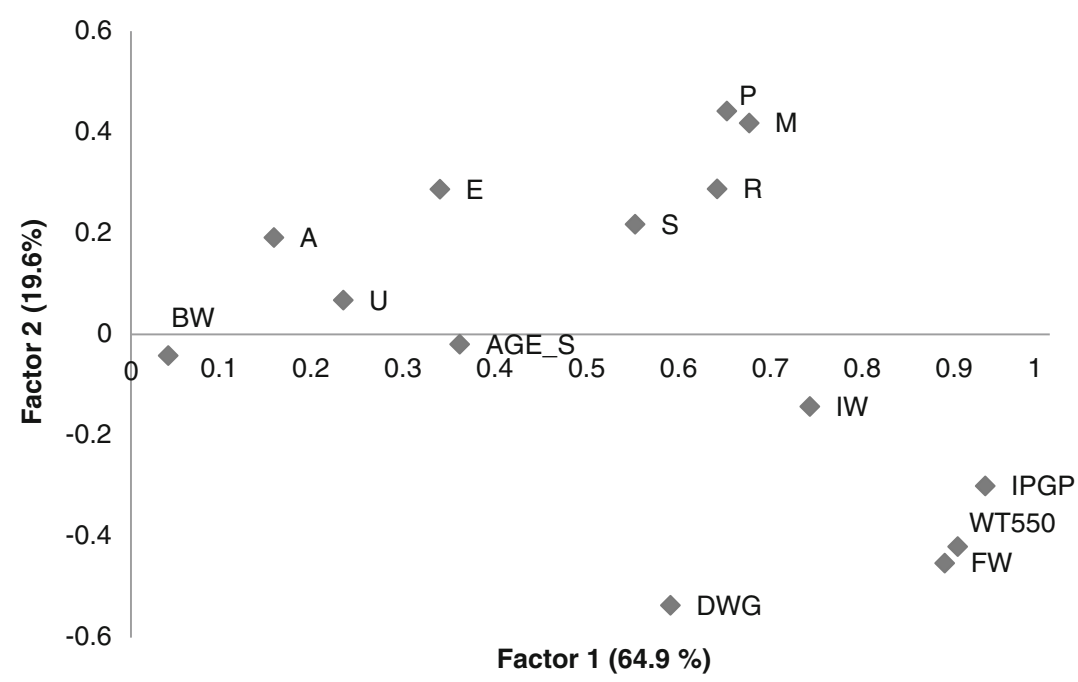


period, among others) may account for the differences between the studies.

Accuracy of progeny testing in different herds is affected by connectability. Low connectivity, due to bulls having a low number of offspring in few herds, helps to increase the systematic differences between progeny groups, compromising the accuracy of genetic evaluation (Carneiro et al. 2001). Here was a strong connectability among TGs, so the genetic evaluation should be accurate.

Production traits had moderate to high positive genetic and phenotypic correlations between each other (Table 3) as expected. Malhado et al. (2002) and Santos et al. (2005) found high correlations between weights at 205 and 550 days of age (close to this work). These results show that intermediate weights have high correlations with subsequent weighings, indicating that animals may be selected early in life.

Boligon et al. (2009) reported a genetic correlation of 0.26 between birth weight and yearling weight in Nelore cattle. This is higher than that found in this study (0.05), together with the correlations for BW with IW and BW with FW of 0.09 and 0.06 , respectively, which are all positive and low, thereby indicating that BW should not be recommended as a selection criterion to obtain heavier animals at later ages. The difference in estimates is possibly due to differences in environmental, genetic, or maternal factors.

Among visual scores, E, $\mathrm{P}$, and $\mathrm{M}$ had high and positive phenotypic correlations, approximately 0.65 for $\mathrm{E}$ with $\mathrm{P}$ and $\mathrm{M}$, and higher between P and M (0.74). According to Koury Filho et al. (2010), selection for one visual score is likely to mean a positive correlated response in all the others at the same or different ages. Araújo et al. (2010) found that these

Table 5 Average characteristics of each cluster for growth and visual characteristics of Nelore bulls in central performance tests at pasture

\begin{tabular}{llllll}
\hline Cluster variables & 1 & 2 & 3 & 4 & 5 \\
\hline E$^{*}$ & 3.25 & 3.87 & 4.22 & 4.56 & 5.10 \\
$\mathrm{P}^{*}$ & 3.02 & 3.62 & 3.90 & 4.17 & 4.69 \\
$\mathrm{M}^{*}$ & 2.83 & 3.48 & 3.80 & 4.13 & 4.65 \\
$\mathrm{U}^{*}$ & 2.95 & 3.15 & 3.21 & 3.35 & 3.56 \\
$\mathrm{R}^{*}$ & 2.60 & 2.88 & 3.05 & 3.16 & 3.36 \\
A $^{*}$ & 2.87 & 3.01 & 3.12 & 3.16 & 3.24 \\
$\mathrm{~S}^{*}$ & 2.35 & 2.90 & 3.25 & 3.41 & 3.58 \\
DWG $(\mathrm{kg})$ & 0.367 & 0.467 & 0.555 & 0.656 & 0.765 \\
IW $(\mathrm{kg})$ & 185.04 & 210.23 & 233.41 & 256.36 & 289.46 \\
FW $(\mathrm{kg})$ & 267.23 & 314.84 & 357.74 & 403.40 & 460.86 \\
WT550 $(\mathrm{kg})$ & 269.35 & 314.33 & 355.80 & 398.93 & 450.28 \\
\hline
\end{tabular}

*Average score of each visual trait

$E$ body structure, $P$ early maturing, $M$ muscle, $U$ navel, $R$ breed standard, $A$ posture, $S$ sexual characteristics, $D W G$ growth rate, $I W$ initial weight on test, $F W$ final weight on test, WT550 calculated weight at 550 days
Table 6 Distribution of animals correctly identified in clusters using visual and performance data in Nelore bulls reared at pasture

\begin{tabular}{llllll}
\hline & \multicolumn{5}{l}{ Cluster } \\
\cline { 2 - 6 } & 1 & 2 & 3 & 4 & 5 \\
\hline 1 & 97.04 & 0 & 2.22 & 0 & 0.74 \\
2 & 0 & 99.72 & 0 & 0 & 0.28 \\
3 & 0.89 & 0 & 97.52 & 1.59 & 0 \\
4 & 0 & 0 & 2.59 & 97.41 & 0 \\
5 & 0.41 & 1.64 & 0 & 0 & 97.94 \\
Total (\%)* & 8.4 & 22.86 & 33.96 & 24.05 & 10.73 \\
\hline
\end{tabular}

*Percentage of all animals in the data bank in each cluster

scores describe the potential of the animal for meat production as a whole, as they are directly linked to the animal's body weight. They suggest that the trait that is more easily measured, with high heritability and less influenced by the evaluator, could be recommended as a selection criterion.

Genetic correlation between $\mathrm{E}$ and $\mathrm{P}$ was 0.93 , between $\mathrm{E}$ and $\mathrm{M}$ was 0.80 , and between $\mathrm{P}$ and $\mathrm{M}$ was 0.98 , corroborating in Araújo et al. (2010) results. Working with C, P, and $\mathrm{M}$, Araújo et al. also found high correlations of $\mathrm{P}$ with $\mathrm{C}$ and $\mathrm{M}(0.85$ and 0.90 , respectively) and $\mathrm{P}$ with $\mathrm{M}$ of 0.85 , but these results are different from Faria et al. (2010) who observed only a high correlation of $\mathrm{P}$ with $\mathrm{M}(0.85)$ and low to moderate correlations with $\mathrm{P}$ and $\mathrm{M}$ values of 0.11 and 0.23 , respectively. These results indicate that careful use should be made of these correlations when developing breeding programs.

As all genetic correlations between visual score and weights were positive, it remains to be seen if these would bring additional gains in breeding programs as animals are already being selected for weight and weight gain. Koury Filho et al. (2010) reported that the correlations between scores and standard weights should be considered, as selection solely for weight can lead to the emergence of economically unviable biotypes. The present study demonstrates that the use of these characteristics as selection criteria is feasible if the

Table 7 Traits responsible for differences between clusters of Nelore bulls on central performance tests at pasture

\begin{tabular}{lllll}
\hline Cluster & 2 & 3 & 4 & 5 \\
\hline 1 & WT550, E, U & WT550, E, S & WT550, E & WT550, E, S \\
2 & - & WT550, E, M & WT550 & WT550, E, M \\
3 & - & - & WT550, E, M & WT550, E, S \\
4 & - & - & - & WT550, E, S
\end{tabular}

$E$ body structure, $P$ early maturing, $M$ muscle, $U$ navel, $R$ breed standard, $A$ posture, $S$ sexual characteristics, $D W G$ growth rate, $I W$ initial weight on test, $F W$ final weight on test, WT550 calculated weight at 550 days 
farmer wishes to obtain heavy animals that are early developing and structurally suitable for a good meat yield.

Moderate to high genetic correlations were seen between growth and visual characteristics (Table 3 ) generally above 0.4 , being higher than that found by Koury Filho et al. (2010), who reported correlations among 550-day weight and conformation, precocity, and musculature, ranging from 0.58 to 0.83 . These results indicate that the use of these traits in genetic selection indices should achieve satisfactory results in breeding programs with this breed. In general, A had the lowest genetic correlations with the other traits.

The highest heritabilities and lower AIC scores were seen using TG as fixed for growth traits and random for visual characteristics (Table 3). Heritability estimates in the univariate analysis for production traits (DWG, FW, WT550) were moderate to high (Table 4), ranging from 0.26 to 0.50 . These results indicate that the selection for these traits can show reasonable genetic gain. The heritability for WT550 was 0.46 , considered moderately high, in agreement with several other studies (Faria et al. 2011; Pedrosa et al. 2010). For DWG, $h^{2}$ was 0.26 , higher than that found by Koury Filho et al. (2003) where working with weight gain from weaning to yearling found an $h^{2}$ of 0.14 . This may reflect differences between genetic material or ages and management.

E, P, and $\mathrm{M}$ showed low to moderate heritabilities $(0.19$, 0.25 , and 0.20 , respectively) similar to the results found by Pedrosa et al. (2010) and Araújo et al. (2010) who obtained a heritability of 0.23 and 0.16 respectively for C, 0.19 and 0.17 for $\mathrm{P}$, and 0.22 and 0.16 for $\mathrm{M}$. These are lower than heritabilities found by Boligon and Albuquerque (2010) and Boligon et al. (2010, 2011) (also working with CPM). These results indicate genetic gains with the use of these traits in selection programs. R, A, and S showed low heritabilities, from 0.05 to 0.15 , showing a low selection response.

Navel heritability was 0.36 , which is higher than that observed by Koury Filho et al. (2003) and Bignardi et al. (2011). These studies were carried out on-farm and not under more controlled conditions of a central performance test with standardization of age and type. This result indicates that the selection for navel can bring satisfactory results.

The first two components (Fig. 2) explained $77.2 \%$ of the variance between characteristics. In the first component, growth and reproductive characteristics (IW, FW, and DWG), varied with the visual characteristics (P, M, E, and S). In general, selection for one trait should improve the others. In the second component, there was a subgroup of animals where production traits were antagonistic to visual characteristics. There were individuals that were positively rated for visual traits with poor growth and vice versa. These animals should be identified as they may not be suitable for reproduction.

Animals were separated into five clusters based on visual and growth traits. Clusters 1 and 2 were formed by animals classified as inferior in EPMURAS and lower than the average growth rates (Table 5); in cluster 3, animals were medium for all traits while the clusters 4 and 5 are composed of the best animals classified by visual assessment, weights, and growth rates. The cluster means show the difference between biotypes. Cluster 1 contained $8.4 \%$ of the animals analyzed, $22.86 \%$ of the animals were in cluster $2,33.96 \%$ in cluster 3, $24.05 \%$ in cluster 4 , while the remaining $10.73 \%$ were in cluster 5 . In all cases, more than $97 \%$ of the animals were correctly designated their own clusters in a discriminant analysis (Table 6). WT550 and E were important in separating most clusters (Table 7), while $\mathrm{U}, \mathrm{S}$, and $\mathrm{M}$ were important in separating individual clusters. This means that careful attention should be given to these traits when selecting animals for reproduction.

\section{Conclusions}

Heritability and genetic correlations indicate that the use of visual scores, along with development traits can improve selection of Nelore beef cattle at pasture. In particular, selection for structure, precocity, and muscle development should bring favorable results in terms of animal conformation. Different shapes of animals can be defined, which need to be further investigated.

Acknowledgments Thanks are due to $\mathrm{ABCZ}$ for data, CAPES for scholarships and INCT-Pecuária/CNPq/FAPEMIG for further funding.

\section{References}

Araújo, R.O., Rorato, P.R.N., Weber, T., Everling, D,M, Lopes, J.S., Dornelles, M.A., 2010. Genetic parameters and phenotypic and genetic trends for weight at weaning and visual scores during this phase estimated for Angus-Nelore crossbred young bulls. Revista Brasileira de Zootecnia, 39, 2398-2408.

Barcellos, J.O.J., Querioz Filho, L.A., Ceolin, A.C., Gianezini, M., McManus, C., Malafaia, G.C., Oaigen, R., 2011. Technological innovation and entrepreneurship in animal production. Revista Brasileira de Zotecnia, 40, Special Supplement, 189-200.

Bignardi, A.B., Gordo, D.G.M., Albuquerque, L.G., Sesana, J.C., 2011. Parâmetros genéticos de escore visual do umbigo em bovinos da raça Nelore. Arquivo Brasileira de Medicina Veterinária e Zootecnia, 63, 941-947.

Boldman, K.G., Kriese, L.A., Van Vleck, L.D., Van Tassell, C.P., Kachman, S.D., 1995. A manual for use for MTDFREML. A set of programs to obtain of variance and covariances. Agricultural Research Service, 120p.

Boligon, A.A., Albuquerque, L.G., 2010. Correlações genéticas entre escores visuais e características reprodutivas em bovinos Nelore usando inferência bayesiana. Pesquisa Agropecuária Brasilera, $45,1412-1418$.

Boligon, A.A., Albuquerque, L.G., Mercadante, M.E.Z., Lôbo, R.B., 2009. Herdabilidades e correlações entre pesos do nascimento à 
idade adulta em rebanhos da raça Nelore. Revista Brasileira de Zootecnia, 38, 2320-2326.

Boligon, A.A., Mercadante, M.E.Z., Albuquerque, L.G., 2010. Genetic associations of conformation, finishing precocity and muscling visual scores with mature weight in Nelore cattle. Livestock Science, 135, 238-243.

Boligon, A.A., Mercadante, M.E.Z., Baldi, F., Lôbo, R.B., Albuquerque, L.G., 2011. Multi-trait and random regression mature weight heritability and breeding value estimates in Nelore cattle, South African Journal of Animal Science, 40, 145-148.

Carneiro, A.P.S., Torres, R.A., Euclydes, R.F., Silva, M.A., Lopes, O.S., Carneiro, P.L.S., Torres Filho, R.A., 2001. Efeito da conexidade de dados sobre a acurácia dos testes de progênie e performance. Revista Brasileira de Zootecnia, 30,342-347.

Conceição, F.M., Ferraz Filho, P.B., Silva, L.O.C., Bragança, V.L.C., Souza, J.C., 2005. Fatores ambientais que influenciam o peso a desmama, ano e sobreano em bovinos da raça nelore mocha, no sudeste de Mato Grosso do Sul - Brasil. Archives of Veterinary Science, 10,157-165.

Ministério da Agricultura, Pecuária e Abastecimento - MAPA, 2010. Projeções do Agronegócio, Brasil 2009/2010 a 2019/2020. Assessoria de Gestão Estratégica. - Brasília, Mapa/ACS, 76 p.

Faria, C.U., Magnabosco, C.U., Albuquerque, L.G., Los Reyes, A., Bezerra, L.A.F., Lôbo, R.B., 2008. Estimativas de correlações genéticas entre escores visuais e características de crescimento em bovinos da raça nelore utilizando modelos bayesianos linearlimiar. Ciência Animal Brasileira, 9, 327-340.

Faria, C.U., Iwres, B.C., Vozzi, A.P., Magnabosco, C.U., Koury Filho, W., Viu, M.A., Oliveira, H.N., Lôbo, R.B., 2010. Genetic correlations between categorical morphological traits in Nelore cattle by applying Bayesian analysis under a threshold animal model. Journal of Animal Breeding and Genetics, 127,377-384.

Faria, L.C., Queiroz, A.S., Vozzi, P.A., Lôbo, R.B., Bezerra, L.A.F., Magnabosco, C.U., Oliveira, E.J.A., 2011. Estudo genético quantitativo de características de crescimento de bovinos da raça Brahman no Brasil. ARS Veterinária, 27,30-35.

Ferraz, J.B.S., Felício, P.E., 2010. Production systems - an example from Brazil. Meat Science, 84, 238-243.

Gutiérrez, J.P., Goyache, F., 2002. Estimation of genetic parameters of type traits in Asturiana de los Vales beef cattle breed. Journal of Animal Breeding and Genetics, 119, 93-100.

Josahkian, L.A., Machado, C.H.C., Koury Filho, W., 2003. Programa de melhoramento genético das raças zebuínas - Manual de Operação. Uberaba, MG, Associação Brasileira de Criadores de Zebu $\mathrm{ABCZ}, 98 \mathrm{p}$.

Koury Filho, W., Jubileu, J.S., Eler, J.P., Ferraz, J.B.S., Pereira, E., Cardoso, E.P., 2003. Parâmetros genéticos para escore de umbigo e características de produção em bovinos da raça Nelore. Arquivo Brasileira de Medicina Veterinária e Zootecnia, 55,594-598.
Koury Filho, W., Albuquerque, L.G., Alencar, M.M., Forni, S., Silva, J.A.V., Lôbo, R.B., 2009. Estimativas de herdabilidade e correlações para escores visuais, peso e altura ao sobreano em rebanhos da raça Nelore. Revista Brasileira de Zootecnia, 38,2362-2367.

Koury Filho, W., Albuquerque, L.G., Forni, S., Silva, J.Á., Yokoo, M.J., Alencar, M.M., 2010. Estimativas de parâmetros genéticos para os escores visuais e suas associações com peso corporal em bovinos de corte. Revista Brasileira de Zootecnia, 39,1015-1022.

Malhado, C.H.M., Souza, J.C., Silva, L.O.C., Ferraz Filho, P.B., 2002. Correlações genéticas, fenotípicas e de ambiente entre os pesos de várias idades em bovinos da raça Guzerá no estado de São Paulo. Archives of Veterinary Science, 7,71-75.

Malhado, C.H.M., Carneiro, P.L.S., Malhado, A.C.M., Martins Filho, R., Bozzi, R., Ladle, R.J., 2010 Genetic improvement and population structure of the Nelore breed in Northern Brazil. Pesquisa Agropecuária Brasileira, v.45, n.10, 1109-1116

McHugh, N., Evans, R.D., Fahey, A.G., Berry, D.P., 2012. Animal muscularity and size are genetically correlated with animal liveweight and price. Livestock Science, 144,11-19

Metz, P.A.M., Menezes, L.F.G., Arboitte, M.Z., Brondani, I.L., Restle, J., Callegaro, A.M., 2009. Influência do peso ao início da terminação sobre as características de carcaça e da carne de novilhos mestiços Nelore $\times$ Charolês. Revista Brasileira de Zootecnia, 38,346-353.

Neter, J., Kutner, M.H., Nachtsheim, C.J., Wasserman, W., 1996. Applied linear statistical models (4 ed.). Homewood, IL: Irwin.

Pedrosa, V.B., Eler, J.P., Ferraz, J.B.S., Silva, J.Á., Ribeiro, S., Pinto, L.F.B., 2010. Parâmetros genéticos do peso adulto e características de desenvolvimento ponderal na raça Nelore. Revista Brasileira de Saúde e Produção Animal, 11,104-113.

Roso, V.M., Schenkel, F.S., 2006. AMC - A computer program to assess the degree of connectedness among contemporary groups. In: Proceedings of the 8th World Congress on Genetics Applied to Livestock Production, Belo Horizonte, Brazil, CDROM.

Santos, P.F., Malhado, C.H.M.M., Carneiro, P.L.S., Martins Filho, R., Azevêdo, D.M.M.R., Cunha, E.E., Souza, J.C., Ferraz Filho, P.B., 2005. Correlação genética, fenotípica e ambiental em características de crescimento de bovinos da raça Nelore variedade mocha. Archives of Veterinary Science, 10,55-60.

Vallimont, J.E., Dechow, C.D., Daubert, J.M., Dekleva, M.W., Blum, J.W., Barlieb, C.M., Liu, W., Varga, G.A., Heinrichs, A.J., Baumrucker, C.R., 2010. Genetic parameters of feed intake, production, body weight, body condition score, and selected type traits of Holstein cows in commercial tie-stall barns, Journal of Dairy Science, 93, 4892-4901

Yokoo, M.J., Lobo, R.B., Araujo, F.R.C., Bezerra, L.A.F., Sainz, R.D., Albuquerque, L.G., 2010. Genetic associations between carcass traits measured by real-time ultrasound and scrotal circumference and growth traits in Nelore cattle. Journal of Animal Science, 88, 52-58. 